\title{
Proceedings of the 66th Annual Meeting of Southern Region
}

\author{
Saga. November 5-6, 2016
}

\section{Contributed Papers}

1. The inspection of gene expression vector on tick cell.

Ido, A., Masatani, T., Yoshii, K., Galay, R. L., Kusakisako, K., Talactac, M. R., Hernandez, E. P., Mochizuki, M. and Tanaka, T.

2. Identification and antibacterial activity of hemolymph defensin from the hard tick Haemaphysalis longicornis.

Yada, Y., Kusakisako, K., Talactac, M. R., Hernandez, E. P., Maeda, H., Mochizuki, M., Fujisaki, K. and Tanaka, T.

3. Molecular identification of blood meals ingested by female black flies caught in a wild boar shed, Oita, Japan.

Fukuda, M., Otsuka, Y. and Takaoka, H.

4. Control of dengue fever vector mosquitoes in Piis-Paneu Island of the Federated States of Micronesia.

5. Mosquito control in a University campus (2). Otsuka, Y., Yamamoto, S., Kawanishi, M. and Noda, S. 


\section{第66回日本衛生動物学会南日本支部大会講演要旨}

会 期 2016年11月5-6日

会 場 佐賀大学 医学部 鍋島キャンパス

\section{一般講演}

1. マダニ胚由来細胞における遺伝子発現ベクターの検証 .. 井戸明子 ${ }^{1)}$, 正谷達謄 ${ }^{2}$ ，好井健太朗 ${ }^{3)}$, Remil L. Galay ${ }^{1)}$, 草木迫浩大 ${ }^{1)}$,

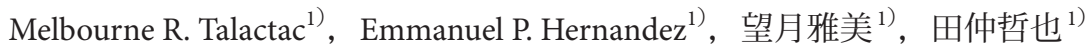
(1) 鹿児島大学・共同獣医学部・感染症学分野, ${ }^{2}$ 鹿児島大学・共同獣医学部・TADセンター, 3) 北海道大学・大学院獣医学研究科・公衆衛生学教室） 75

2. フタトゲチマダニへモリンフ由来ディフェンシンの同定とその抗菌作用 屋田友里花 ${ }^{1)}$ ，草木迫浩大 ${ }^{1)}$ ， Melbourne R. Talactac ${ }^{1)}$ ，Emmanuel P. Hernandez ${ }^{1)}$, 前田大輝 ${ }^{1)}$, 安藤匡子 ${ }^{2)}$, 望月雅美 ${ }^{1)}$, 藤崎幸蔵 ${ }^{3)}$, 田仲哲也 ${ }^{1)}$ (1) 鹿児島大学・共同獣医学部・感染症学分野, 2) 鹿児島大学・共同獣医学部・公衆衛生学分野, 3) 農研機構) 75

3. 大分県でイノシシ囮法により採集されたブユ成虫の吸血源動物の同定 福田昌子 ${ }^{1)}$, 大塚 靖 $^{2)}$, 高岡宏行 ${ }^{3)}$

(1) 大分大・全学研究推進機構， ${ }^{2}$ 鹿児島大・国際島嶼教育研究センター, 3) マラヤ大・理・生物学研究所） 75

4. ミクロネシア連邦ピス島でのデング熱媒介蚊対策の実践 .. 大塚 靖 ${ }^{1)}$, 山本宗立 ${ }^{1}{ }^{1}$, 川西基博 ${ }^{2}$, 野田伸一 ${ }^{1)}$

(1) 鹿児島大学国際島嶼教育研究センター， ${ }^{2}$ 鹿児島大学教育学部) 75

5. 大学構内における蚊の防除の試み（続報） 砂原俊彦（長崎大学熱帯医学研究所） 
マダニ胚由来細胞における遺伝子発現ベクターの検証

1 O井戸明子 ${ }^{1)}$, 正谷達謄 ${ }^{2)}$, 好井健太朗 ${ }^{3)}$, Remil L. Galay ${ }^{1)}$, 草 木迫浩大 ${ }^{1)}$ ， Melbourne R. Talactac ${ }^{1}$ ， Emmanuel P. Hernandez ${ }^{1}$, 望月雅美 ${ }^{1)}$, 田仲哲也 ${ }^{1)}\left(^{(1)}\right.$ 鹿児島大学・共同獣医学部・感染 症学分野, ${ }^{2}$ 鹿児島大学・共同獣医学部・TADセンター, ${ }^{3)}$ 北海道大 学・大学院獣医学研究科・公衆衛生学教室)

The inspection of gene expression vector on tick cell. Ido, A., Masatani, T., Yoshii, K., Galay, RL., Kusakisako, K., Talactac, MR., Hernandez, EP., Mochizuki, M. and Tanaka, T.

マダニは様々な病原体を媒介するために医学・獣医学分野において重 要な生物である. マダニの遺伝子機能を解析する上で, 遺伝子操作系は 非常に有用なツールであるものの, マダニの遺伝子操作系は未だ発展途 上である. そこで本研究では, 遺伝子操作系を確立する上で必要となる, マダニ細胞内で外来遺伝子を高発現する遺伝子発現ベクターを探索並び に構築することを目的とした.

哺乳類扔よび昆虫細胞発現ベクターを基にしたルシフェラーゼ活性は, pmirGLO, pCAGGS-MCS, pEF-BOS $(+)$, pcDNA3.1 $(+)$, pIEx/Bac-3の 順に高かった. pmirGLO並びにpCAGGSの活性は特に高いことから，こ れらの発現ベクターはマダニ細胞においても有用であると考えられた. pmirGLO およびpCAGGSのプロモーター配列を，マダニアクチン遺伝子 の推定プロモーター配列に置換したルシフェラーゼ活性は, 前者では無 置換のものと同等であり, 後者では無置換のものの 2 分の 1 程度であっ た. これらのことから, マダニアクチン遺伝子の推定プロモーター配列 はマダニ細胞内で活性を持つことが明らかになった. 以上の結果より, pmirGLO 打よびpmirGLOのプロモーター配列をマダニアクチン遺伝子の 推定プロモーター配列に置換した発現ベクターは, マダニ遺伝子操作系 の確立において, 遺伝子高発現ベクターとして使用できることが示唆さ れた.

\section{大分県でイノシシ四法により採集されたブユ成虫の吸血源動} 3 物の同定

$\bigcirc$ 福田昌子 ${ }^{1)}$, 大塚 靖 ${ }^{2}$, 高岡宏行 ${ }^{3)}\left({ }^{(1)}\right.$ 大分大 $\cdot$ 全学研究 推進機構, ${ }^{2)}$ 鹿児島大・国際島嶼教育研究センター, ${ }^{3)}$ マラ ヤ大・理・生物学研究所)

Molecular identification of blood meals ingested by female black flies caught in a wild boar shed, Oita, Japan. Fukuda, M., Otsuka, Y. and Takaoka, H.

われわれは日本の動物寄生性オンコセルカの人体感染例を報告する過 程で, 大分の症例の起因種がイノシシに寄生する新亜種 Onchocerca dewittei japonica (O. d. j.) であること, その媒介者がヒト吸血性キアシツメト ゲブユS Simulium bidentatumである可能性が高いことを明らかにしてきた. 媒介者の検索は, 感染実験とフィラリア幼虫の自然感染の調査で, ブユ 成虫から O d. j.の感染幼虫（第3期幼虫）を見いだすことにより行った が，自然界で実際にブユがイノシシを吸血するかは不明であった。そこ で，イノシシ囮法で採集したブユ成虫の吸血源動物の同定を試みた。 大 分県に扔いて，イノシシに誘引されたブユ成虫を捕虫網で採集し，飽血 個体の吸血源動物のDNAを抽出した。 ミトコンドリアDNA のコントロー ル領域と核DNAの Glucosephosphate isomerase-processed pseudogene (GPIP 遺伝子）をPCR増幅し，得られた断片の塩基配列を解析した。採集され たキアシツメトゲブユとヒト吸血性ヒメアシマダラブユS. arakawaeの飽 血個体を分析した結果, ミトコンドリアDNAのハプロタイプは両種とも にJ15であった. GPIP遺伝子型は前者では GPIP* $1 / G P I P^{*} 3$ 型であったが, 後者では検出できなかった。 いずれもニホンイノシシに特徴的なアジア 型で，両種が吸血した動物はイノシシである可能性が高いと考えられた (キアシツメトゲブユの結果の一部は第68回日本衛生動物学会大会で発表 した). 感染実験でヒメアシマダラブユからも感染幼虫が見いだされてお り，キアシツメトゲブユだけでなく本種も O d d . j.の媒介者となり得るこ とが示唆された.

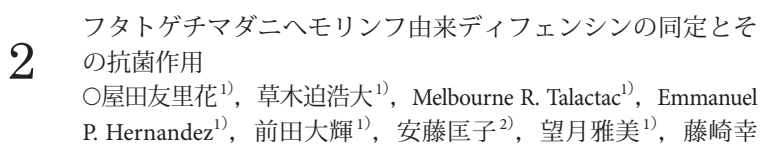
蔵 ${ }^{3)}$, 田仲哲也 ${ }^{1)}\left({ }^{1}\right)$ 鹿児島大学・共同獣医学部・感染症学分野, ${ }^{2}$ 鹿児 島大学・共同獣医学部・公衆衛生学分野, ${ }^{3}$ 農研機構)

Identification and antibacterial activity of hemolymph defensin from the hard tick Haemaphysalis longicornis. Yada, Y., Kusakisako, K., Talactac, MR., Hernandez, EP., Maeda, H., Mochizuki, M., Fujisaki, K. and Tanaka, T.

マダニは吸血によって保有する病原体を宿主へ伝播する一方で, 自然 免疫を発達させることで, 自らの病原体感染を防御している. 自然免疫 系の一種である抗菌ぺプチドは病原体感染から直接的に生体を防御して いる分子であり, その代表的なものとしてディフェンシンが挙げられる. そこで, フタトゲチマダニのへモリンフディフェンシン（HEディフェン シン）に着目し，その特性を解明するために本研究を行った。

HEディフェンシン遺伝子の全長解析を行ったところ, ORF $225 \mathrm{bp}$, 推定産物は 74 アミノ酸からなり, 推定分子量は約 $8.15 \mathrm{kDa}$ であった。 ま た, 等電点は 9.48 と推定され, 塩基性ペプチドであることが予想された. さらに, HEディフェンシンは6つのシステイン残基を保有しており, 他 のマダニディフェンシンとアミノ酸相同性を示した. HEディフェンシン はグラム陽性菌であるMicrococcus luteus, Staphylococcus aureus, Bacillus cereusに対して増殖抑制を示し, 特に M. luteusに対して強い抗菌活性を示し た. また, 蛍光抗体法により, HEディフェンシンがM. luteusへ結合する 蛍光像が観察された. M. luteusの膜透過性の変化を調べたところ, HE ディフェンシンが細胞膜に直接傷害をもたらす蛍光像が観察された．以 上の結果から, HEディフェンシンは細菌の細胞膜に結合することで細菌 の增殖を制御している可能性が考えられた。
ミクロネシア連邦ピス島でのデング熱媒介蚊対策の実践

4 大塚 靖 ${ }^{1)}$, 山本宗立 ${ }^{1)}$, 川西基博 ${ }^{2)}$, 野田伸一 ${ }^{1)}$ (1) 鹿児島 大学国際島嶼教育研究センター, ${ }^{2)}$ 鹿児島大学教育学部)

Control of dengue fever vector mosquitoes in Piis-Paneu Island of the Federated States of Micronesia. Otsuka, Y., Yamamoto, S., Kawanishi, M. and Noda, S.

ミクロネシア連邦のデング熱対策として，特に医療機関のない離島で は, 媒介蚊の発生源の除去が重要となる。ミクロネシア連邦チューク州 ピス島において，住民に対してデング熱に関する説明会を開き，パンフ レット配布やDVD 上映などで蚊の対策が重要であることを説明し，島の コミュニティーでの対策を促し, その過程で蚊の発生源がどのように変 化するのかを調べた。 2012 年〜2014年にピス島で居住区すべてにおいて, 水の溜まった容器数, 容器の種類, 蚊幼虫の生息, 蚊の種類を世帯ごと に調査した. その結果, ピス島にはAedes hensilli, Ae. scutoscriptus, Culex quinquefasciatus, C. carolinensis, C. annulirostrisの5種が分布するが, 種に よって生息する容器に違いがみられ, C. quinquefasciatus と C. annulirostris は人工容器（プラスチック容器, コンクリート製水タンク, ドラム午, 小型金属容器等）を主に生息地として利用し, Ae. hensilli, Ae. scutoscriptus, C. carolinensisは人工容器と天然容器（ココヤシ殼, バナナ株, 樹洞 等）を共に利用していた. ピス島ではミクロネシア連邦ヤップ州同様に Ae. hensilliがデング熱の媒介種と考えられ, 人工容器だけではなく, 天然 容器, 特に発生が多かったココヤシ殼の対策も重要となる. 年別の発生 容器数は 165 個（2012年), 171個（2013年), 100個（2014年）であった. 2013年には僅かに増加したが，2014年には大きく減少した．世帯ごとの 発生容器数は, 2012年は一世帯に3 個の発生容器数がある世帯が一番多 かったが, 2012 年には 2 個, 2014 年には 1 個発生容器数がある世帯が最も 多かった. 発生容器は特定の世帯で多い傾向にあり, すべての住民が媒 介蚊対策の重要性を理解し実践することの難しさも表れた. 


\footnotetext{
大学構内における蚊の防除の試み（続報）

5 砂原俊彦 (長崎大学熱帯医学研究所).

Mosquito control in a University campus (2). Sunahara, T.
}

2014年夏に東京を中心に約 70 年ぶりの国内流行起こしたデング熱や, 2015年より南米で大きな社会問題となっているジカ熱は, 東北地方以南 の日本各地にきわめて普通に生息するヒトスジシマカによっても媒介さ れる. ヒトスジシマカの活動が活発な季節には日本のどこでもデング熱 やジカ熱の流行が起こりうる状態といえる．特に2014年のデング熱流行 の中心になった代々木公園のような, 日中多くの人が訪れる公共の緑地 は潜在的に流行が起きるリスクが高い場所と考えられる.

大学の敷地は都市公園のモデル的な環境であると同時に，それ自体が デング熱・ジカ熱流行の中心となるリスクをもつと考え，昨年より長崎 大学医学部キャンパスにおいてヒトスジシマカの生息調査と防除対策を 試みている．昨年度の支部大会ではべースライン時の生息状況として キャンパス内で人梱法により 8 分間あたり平均 30 個体以上という極めて 高い密度で成虫が採集されたことなどを報告した．今回のはその続報と して，昨年より継続してきた雑草の刈り払い活動の報告と，今年度の成 虫密度について報告した．昨年と同時期の調査では，密度が低下した地 点が多かったものの，1箇所で8分間あたり 200 個体を越える著しく生息 密度の高い地点が確認された。これはキャンパス内でも比較的自然植生 が残された丘の中腹で，その近くには 10 個ほどの雨水桝が存在し幼虫の 好適な生息場所となっていた。この結果は，極めて狭い場所より大量の ヒトスジシマカが発生する場合があることを示している．対策の際にこ のような場所を見落とすと効果が著しく低下する可能性がある一方で, 正しく特定できれば少ない労力で大きな効果を上げることも期待できる. 